\title{
EFFECTIVENESS OF STRUCTURED TEACHING PROGRAM ON KNOWLEDGE AND PRACTICE OF NURSES REGARDING BLOOD TRANSFUSION IN MEDICAL AND HEMOLYTIC DEPARTMENTS AT TANTA UNIVERSITY HOSPITAL Afaf Abdelaziz Basal ${ }^{1}$, MoneraBassunyElshemy ${ }^{2}$, Medical Surgical Nursing, \\ ${ }^{1,2}$ Faculty of Nursing, Tanta University, Egypt. \\ E-mail of the corresponding author: drafafbasal@yahoo.com
}

\begin{abstract}
:
Transfusion of blood saves life. An error in blood transfusion, at the same time, takes life. An understanding and knowledge of the path physiology of transfusion reactions, symptoms and treatment is essential to safely administer and monitor transfusion. Aim of the study: to evaluate the effectiveness of structured teaching program on knowledge and practice of nurses on blood transfusion. Material and methods: A quasi-experimental research design was utilized on a convenient sample of 30 nurses. The study was conducted in the general medical and hematological departments at TantaUniversityHospital. Three Tools used for data collection includetool I to assess sociodemographic nurses data and knowledge. Tool II Observation check list sheet:to assess nurse's practice. ToolIII Construction of teaching program. Results: $43.3 \%$ and $93.3 \%$ and $66.7 \%$ respectively of the total sample of nurses pre program ,immediately and after one month of post program had correct answer about blood and blood transfusion. There was progress in information immediately after the program and after one month from the program than before the program $(76.7 \%, 66.3 \%, 26.7 \%)$ respectively . The finding indicated that there was statistical significant difference and improvement of nurses' performance in immediately and after one month of the program from pre the program. Conclusion:there was a great improvement in the knowledge and practice score levels obtained by nurses after implementation of nursing intervention program immediately and after one month of follow up. Recommendation: Nurses are in need for in-service training programs and refreshing courses to improve their knowledge which will reflect on their practice.
\end{abstract}

Key words: blood, blood transfusion, nursing interventions

\section{Introduction:}

Blood transfusions are a lifesustaining and life-saving treatment but they aren't without risk. Conditions that warrant blood transfusions range from acute trauma to intraoperative blood loss to compromised blood-cell production secondary to disease or treatment. If you're a nurse on the front line of patient care, you must be adept at administering blood products safely and managing adverse reactions with speed and confidence. The rules of transfusion: Best practices for blood product administration ${ }^{(1)}$
Thompson et al $\mathbf{2 0 0 8}^{(2)}$ stated that the early recognition and management of adverse effects of transfusion is essential to optimize treatment and reduce patient morbidity and mortality. It is crucial that healthcare practitioners monitor patients receiving transfusion and are able to recognize and act on early signs and symptoms of an adverse event.

Nurses have a responsibility to provide the highest standard of care and all patients have the right to expect this. Nurses are integral to the transfusion process; they are often involved in pre- 
transfusion process; they are often involved in pre-transfusion sampling, provision of patient information requesting blood from the laboratory, collecting blood administration of the transfusion and monitoring the patient's response, during and after the transfusion event. As practitioners they are personally accountable. $^{(3)}$

Blood transfusion is the process of transferring blood or blood products from one person into the circulatory system of another person. Transfusions of blood and blood products may be necessary to treat severe thrombocytopenia, leucopenia, and anemia resulting from a disease process or from treatment. Whole blood, packed red blood cells platelets, plasma and concentrated clotting factors and other blood products replenish volume, oxygen carrying capacity, platelet volume, and clotting factors. This life-saving procedure can be life threatening if not carefully performed in accordance with facility policy and safe nursing practice. ${ }^{(4)}$

Human blood is made of a fluid called plasma $(55 \%)$ that carries red and white blood cells and platelets(45\%). Red blood cells carry oxygen from the lungs to other body organs and carry carbon dioxide back to the lungs. A certain number of these cells are needed for the body to function. Bleeding due to trauma, surgery, or disease may cause a low red blood cell count. White blood cells fight infections by destroying bacteria, viruses, and other germs. White blood cell transfusions are rarely given. They are usually reserved for children who have a low white cell count and severe infection that is not responsive to antibiotic therapy. Platelets help control bleeding by making clots in the blood vessels opened by injury or surgery ${ }^{(5-8)}$.

When the blood or blood components have been obtained from the blood bank, positive identification of the blood donor and recipient must be made. The blood bank is responsible for typing and crosshatching the donor's blood with the recipient's blood. ${ }^{(9)}$ The nurse should make sure that the patient understands the procedure of blood transfusion and the signs and symptoms as itching, hives, swelling, shortness of breath, fever, chills. Fever may be the initial symptom in a more serious reaction such as bacterial contamination or haemolytic reaction should be report, and that he or she agrees with the treatment plan. Take the patient vital signs before the beginning of the transfusion so the nurse have abase line measure; if the patient has abnormal vital signs, such as an elevated fever, call the doctor to clarify when the blood component may be administer. The blood should be administered as soon as it is brought to the patient. It should not be refrigerated on the nursing unite. If the blood not used within $30 \mathrm{~min}$, it should be returned to the blood bank. ${ }^{(10)}(\mathbf{W u}$ and Snyder, 2005)

Blood transfusions complications can be categorized as acute or delayed, which can be divided further into the categories of noninfectious and infectious. Acute complications occur within minutes to 24 hours of the transfusion, whereas delayed complications may develop days, months, or even years later. The AABB (formerly known as the American Association of Blood Banks) uses the term "noninfectious serious hazards of transfusion" to classify noninfectious complications. ${ }^{(11)}$

Blood transfusions sometimes cause transfusion reactions. There are several types of reactions and some are worse than others. Some reactions happen as soon as the transfusion is started, while others take several days or even longer to develop. Many precautions are taken before a transfusion is started to keep reactions from happening. The blood type of the unit is checked many times, and the unit is cross-matched to be sure that it matches the blood type of the person who will get it. After that, both a nurse and blood bank 
EFFECTIVENESS OF STRUCTUREDTEACHING PROGRAM ON etc...

lab technician look at the information about the patient and the information on the unit of blood (or blood component) before it's released. ${ }^{(6,8)}$

The most severe adverse effects of blood transfusion, such as haemolytic reaction and anaphylactic reaction. Anaphylactic reactions have signs of cardiovascular instabilityincluding hypotension,tachycardia, loss of consciousness, cardiac arrhythmia, shock and cardiacarrest will usuallyoccur within the first 15 minutes of starting transfusion or $50 \mathrm{ml}$ of blood infusion. So during the blood transfusion process, the nurse should remain with the patient. To report patient observations include recording vital signs - temperature, pulse respiration and blood pressure. The purpose of undertaking these observations is to ensure that an acute transfusion reaction can be recognized early and dealt with in a timely manner, thereby helping to reduce or prevent transfusion-associated morbidity or mortality. The rate of infusion during this period should be not more than $2 \mathrm{ml} / \mathrm{min}$. After the first $15 \mathrm{~min}$, vital sings are usually retaken, the transfusion should not take more than 4 hours to administer because of the increased risk of bacterial growth in the product once it is out of refrigeration.

Carven, $2007^{(13)}$ stated thatafter blood transfusion the nurse obtain vital signs and compare with baseline measurements then dispose of used materials properly, document procedure in patient's medical record, including patient assessment findings and tolerance to procedure, and monitor patient for response to and effectiveness of the procedure.

Significance of the problem

Nurses negligence in blood transfusion can leads to increase in morbidity and mortality of patients. So researcher has found a need to administer structured teaching program on blood transfusion for nurses in order to increase nurses' knowledge and decrease morbidity and mortality rate

Aim of the study:

To evaluate the effectiveness of structured teaching program on knowledge and practice of nurses on blood transfusion.

Research hypotheses:

There will be significant improvement in knowledge and practice of nurses about blood transfusion.

Subjects and Method

Research design:

Quasi-experimental design was conducted with one group pre and post test.

Setting of the study:

The study was conducted in the general medical departments and hematological diseases unit at Tanta University Hospital. Study subjects:

A convenience sample of all available nurses (about 30 nurses) working in the general medical departments and hematological diseases unit at Tanta University Hospital and who are willing to participate in the study. Tools of data collection:

Three tools were used in this study. Tools were developed by the researchers based on the study of Khalil etal2013 ${ }^{(14)}$ and others researcher after reviewing the related literature. Then the modification and adaptation was based on the aim of the studyand literaturereview.

\section{Tool I : it included two parts}

Part (1) Socio- demographic data of nurses: such as the nurse's names, age, sex, marital status, level of education, years of experience and if they receive any training in the field of blood transfusion ...etc.

- Part (2) Nurses' knowledge: this includes Pre and post test interview questionnaire sheet used to assess nurse's knowledge about blood transfusion definition, indication, types, complications (its signs and symptoms, causes, management, and prevention) and care of patient pre, during and post blood transfusion 


\section{Scoring system:}

The total score of pre/post test questionnaire sheet was 159 marks The total scores about blood and blood transfusion were 83marksand about complication of blood transfusion were 76 marks

- Scores less than $(50 \%)$ were considered poor level.

- Scores (50\%-70\%) were considered satisfactory level.

- Scores more than (70\%) were considered good level.

Tool II : Observation check list sheet: this observation sheet used to assess nurse's practice. It included nurse's intervention towards patients undergoing blood transfusion in different three times (Pre transfusion, during transfusion and post transfusion).

- This tool was used before and immediately after the implementation of the structured teaching program also after one month to evaluate the effect of the structured teaching program on nurse's intervention towards patients undergoing blood transfusion in different three times:

- Pre transfusion procedure steps include:

- Check the patient's identification by asking the patient's name and checking the patient's chart.Double-check the labels with the ABO group and Rh type agrees with the compatibility record.,

- Check that patient's blood has been cross-matched.,

- Check the blood for gas bubbles and any unusual color or cloudiness.

- Check the expiration date on the blood bag.,

- Explain the procedure to the patient,

- Explain the procedure to the patient,

- Hand washing andwear gloves.,

- Measure vital signs,

- Prepare equipment
- Check presence of IV catheter, if not present insert a large size catheter I a large vein.... ..etc.

During blood transfusion procedure which includes:

- Obtain packed blood from the blood bank after theintravenous 1 line is inserted.

- Use special set with drip chamber containing a large filter,

- Make sure that blood transfusion is initiated within 30 min after removal of the blood container from the blood bank refrigerator

- Invert the blood bag gently several times to mix the cells with the plasma.

- Expose the port on the blood bag by pulling back the tubs.

- Insert the remaining $\mathrm{Y}$ set spike into the blood bag.

- Open the filter to expel any residual air within the filter.

- Close the clamp.

- Insert firmly the $\mathrm{Y}$ set into the IV catheter.

- Run the transfusion slowly (10 to15 $\mathrm{drip} / \mathrm{min}$ ) for first 15 minutes.

- Monitor vital signs, .................etc

Post transfusion procedure which includes

- Dispose of used materials properly.

- Obtain vital signs:

- Hand washing.

- Document procedure in patient's medical record, including patient assessment findings and any adverse reaction.

- Document the time the infusion was started and completed.

- Monitor patient for response to and effectiveness of the procedure.

- Signature

Scoring system:

The total score of observation checklist sheet was 136 degree: Each item inchecklist was scored as following:one degrees for each step that done correct and zero for step that was not done. 
- Scores less than (50\%) were considered as poor level of practice.

- Scores (50\%-70\%) were considered as satisfactory level of practice.

- Scores more than $(70 \%)$ were considered as good level of practice.

Tool III: Construction of teaching program:

Aim of this tool is to enhance nurse's knowledge and practice about blood transfusion that help nurses in provision of safe blood transfusion.

- The content of this teaching program developed by the researcher depending on relevant literature review that include: definition of blood and blood transfusion, types of blood transfusion, indication of blood and its components transfusion, period of storage blood and its components and complications of blood transfusion. Also nursing intervention pre, during and post transfusion of blood.

\section{Method}

-Ethical\&administration considerations:-

1- An official permission to carry out the study was obtained from responsible authorities at Faculty of Nursing at Tanta University. Then, the permission was obtained from the hospital administrative authority.

2- The purpose of the study was explained to the nurses and their consent to participate was received and those who were willing to participate were given a questionnaire to answer it. They were also assured of their anonymity and the confidentiality of their responses.

\section{-Field work:-}

3- The questionnaire's validity were checked by 5 experts of nursing staff from the Faculty members in Tanta University.

4- Pilot study was conducted on $10 \%$ ofnurses. This number was excluded from the studied sample to identify the obstacles and problems that may be encountered during data collection.

5-Internal consistency reliability (coefficient alpha) was tested for tools and it was $(=0.987)$

6- The questionnaires were distributed to nurses in the hospital. The tool I was filled through interviewing. The study was carried out at morning shift. Each nurse was observed directly while performed routine blood transfusion procedure by using tool II.

- The application of structured teaching program (tool III) was performed by the researchers, researcher prepared the training places, teaching aids and media (computer, picture and handouts). This was followed by arranging for the teaching schedule based on the contents of the program, number of staff involved, time availability,. Also scheduled with them the teaching sessions for both theoretical and practical and the nurses were divided into small groups, each group contains 4 to 5 nurses. Each group of nurses chooses the optimal time for receiving the teaching sessions whenever they have minimal workload. each group was given 3 sessions.

- Each nurse obtained a copy of the structuredteaching program booklet that included all the training contents.

- Immediately after implementation of the structuredteaching program (tool III). The nurses' knowledge and practice had been evaluated by the researcher through filling the tool I part two and each nurse was observed directly while performed routine blood transfusion care by using tool II..

7- The data collection was completed during the period of 2 months from the beginning of August tothe end of September 2014. 
8- Responding times to all questions in the tool consumed 15 to 20 minutes.

\section{Statistical analysis}

The collected data were organized, tabulated and statistically analyzed using statistical package for social studies (SPSS) version 19. Descriptive measures, including frequency, percentage, arithmetic mean and standard deviation were presented. Qualitative variable are statistically compared using qui square.

$\mathrm{P}$ value was statistically significant at level $0.05 \%$.

\section{Results}

Table (1) Presents the characteristics of studied nursing. The mean age of the nurses was $\mathbf{3 6 . 8 7} \pm \mathbf{7 . 0 8}$. in relation to marital status it was found that $80 \%$ of total sample were married, In relation to the level of education it was found that $100 \%$ of the total sample had diploma degree . Regarding to the experience years in medical department it was found high percent $60 \%$ of the total sample had $\geq 10$ years of experience. Only $20.0 \%$ of the total sample had previously training courses in blood transfusion.

Figure (1) represents correct and complete answer about blood transfusion among studied nurses. It was found that $43.3 \%$ and $93.3 \%$ and $66.7 \%$ respectively of the total sample of nurses preprogram, immediately and after one month of post program had correctand complete answer about blood and blood transfusion.

Figure (2) represents correctand complete answer about Information about complications of blood transfusion among studied nurses, It was found that $26.7 \% \%$ and $76.7 \%$ and 63.3
$\%$ respectively of the total sample pre program ,immediately and after one month of post program were had right and complete answer about complications of blood transfusion.

Table (2) Illustrates levels of information about blood and blood transfusion among studied nurses. The finding indicated that $43.3 \%, 93.3 \%$, $66.7 \%$ respectively of nurses had good level of information Pre-program, Immediately post-program and After one month. Also there was statistical significant improvement

Table (3) represented Levels of information about complication of blood transfusion among studied nurses. The finding indicated that there was statistical significant improvement related to program,immediately postprogram and after one month $\mathrm{P}=0.0011$

Table (4):- Illustrated distribution of the studied nurses according to their common error in blood transfusion procedures. The finding indicated that there was statistical significant difference and improvement of nurses performance in immediately and after one month of the program from pre the program .

Table (5) represented Levels of error in blood transfusion procedures among studied nurses. High percent of nurses made low level of error immediately post-program and after one month. The finding indicated that there was statistical significant improvement related to Pre-program, Immediately post-program and After one month $\mathbf{P}=\mathbf{0 . 0 0 1} \mathbf{F}=\mathbf{1 1 5}$.23. 
EFFECTIVENESS OF STRUCTUREDTEACHING PROGRAM ON etc...

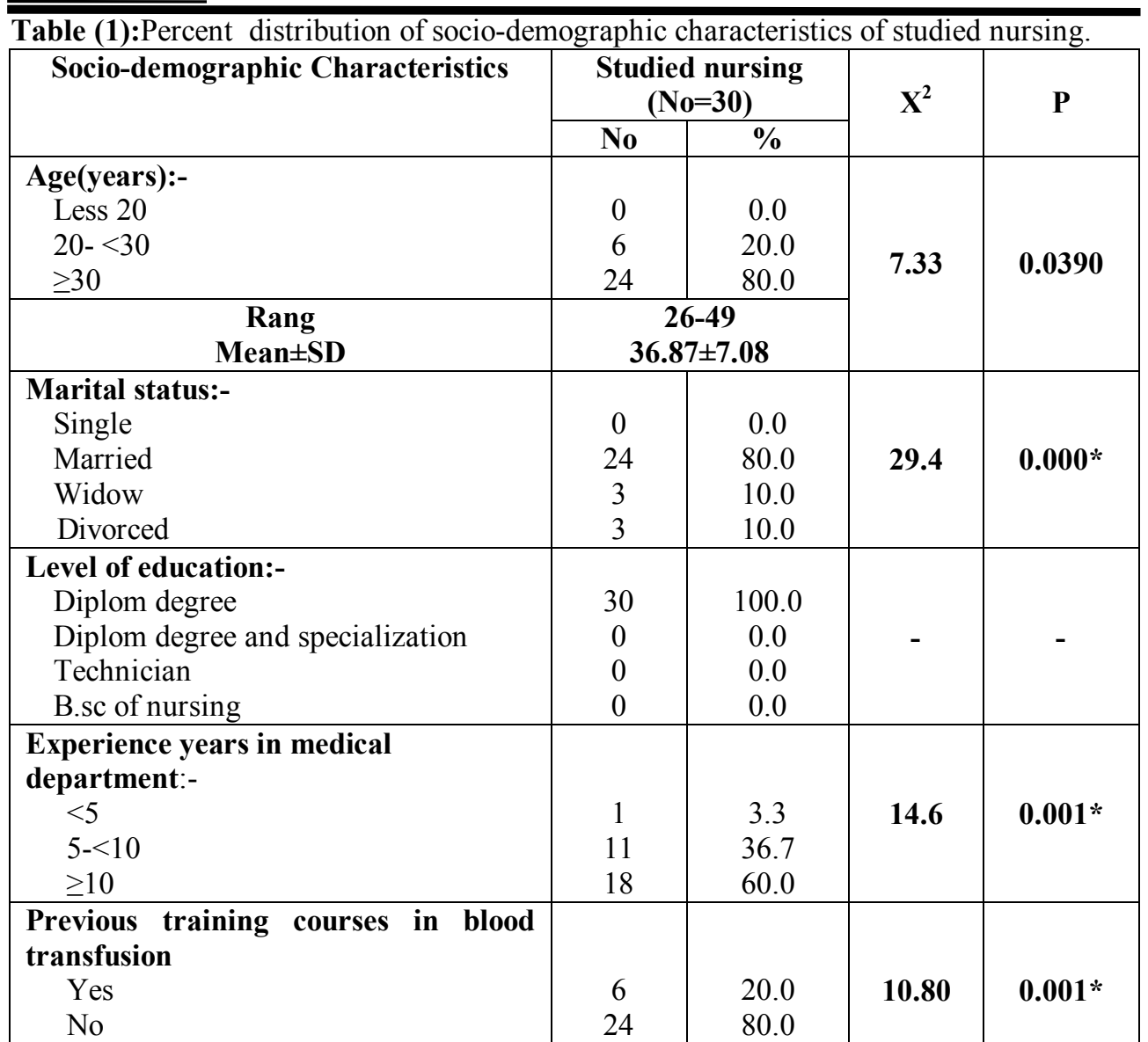

*Significant $\mathbf{P}<0.05$

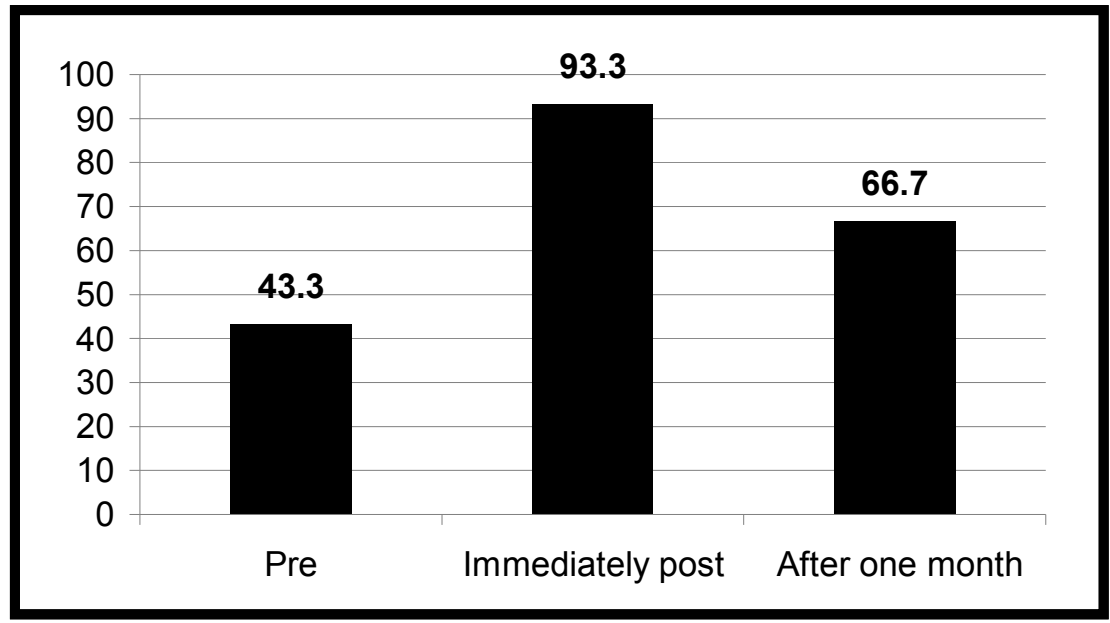

Figure (1):- Correct and complete answer about blood and blood transfusion among studied nurses. 


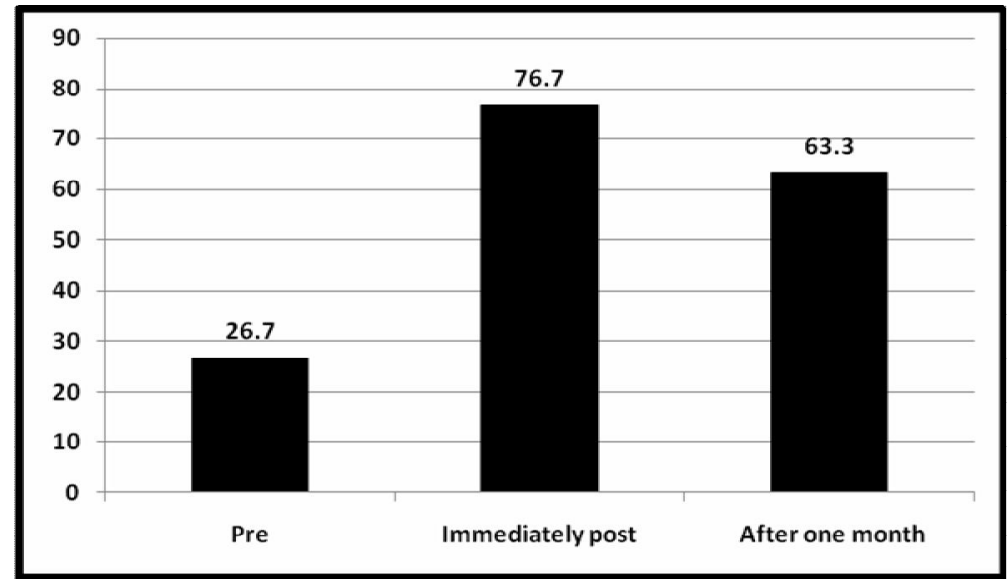

Figure (2):- correct and complete answer about Information about complication of blood transfusion among studied nurses.

Table (2): Levels of information about blood and blood transfusion among Studied nurses.

\begin{tabular}{|c|c|c|c|c|c|c|}
\hline \multirow{3}{*}{ Time of assessment } & \multicolumn{6}{|c|}{$\begin{array}{c}\text { Levels of information about complication of blood } \\
\text { transfusion }(\mathrm{No}=\mathbf{3 0})\end{array}$} \\
\hline & \multicolumn{2}{|c|}{$\begin{array}{c}\text { Poor level } \\
(0-<24)\end{array}$} & \multicolumn{2}{|c|}{$\begin{array}{c}\text { Satisfactory level } \\
(24-34)\end{array}$} & \multicolumn{2}{|c|}{$\begin{array}{c}\text { Good level } \\
(35-48) \\
\end{array}$} \\
\hline & $\mathbf{N}$ & $\%$ & $\mathbf{N}$ & $\%$ & $\mathbf{N}$ & $\%$ \\
\hline Pre-program & 12 & 40.0 & 10 & 33.3 & 8 & 26.7 \\
\hline Immediately post-program & 1 & 3.3 & 6 & 20.0 & 23 & 76.7 \\
\hline After one month & 3 & 10.0 & 8 & 26.7 & 19 & 63.3 \\
\hline $\mathbf{F}$ & \multicolumn{6}{|c|}{$120.12 *$} \\
\hline $\mathbf{P}$ & \multicolumn{6}{|c|}{ 0.0011* } \\
\hline
\end{tabular}

*Significant $\mathrm{P}<0.05$

Table (3):- Levels of information about complication of blood transfusion among Studied nurses.

\begin{tabular}{|c|c|c|c|c|c|c|}
\hline \multirow{3}{*}{ Time of assessment } & \multicolumn{6}{|c|}{$\begin{array}{c}\text { Levels of information about blood and blood } \\
\text { transfusion }(\mathrm{No}=\mathbf{3 0})\end{array}$} \\
\hline & \multicolumn{2}{|c|}{$\begin{array}{c}\text { Poor } \\
(0-<19)\end{array}$} & \multicolumn{2}{|c|}{$\begin{array}{l}\text { Satisfactory } \\
(19-27)\end{array}$} & \multicolumn{2}{|c|}{$\begin{array}{c}\text { Good } \\
(28-38)\end{array}$} \\
\hline & $\mathbf{N}$ & $\%$ & $\mathbf{N}$ & $\%$ & $\mathbf{N}$ & $\%$ \\
\hline Pre-program & 7 & 23.4 & 10 & 33.3 & 13 & 43.3 \\
\hline Immediately post-program & 1 & 3.3 & 1 & 3.3 & 28 & 93.3 \\
\hline After one month & 4 & 13.3 & 6 & 20.0 & 20 & 66.7 \\
\hline $\mathbf{F}$ & \multicolumn{6}{|c|}{ 137.05* } \\
\hline $\mathbf{P}$ & \multicolumn{6}{|c|}{$0.0001 *$} \\
\hline
\end{tabular}

\section{8}


EFFECTIVENESS OF STRUCTUREDTEACHING PROGRAM ON etc...

Table (4) Distribution of the studied nurses according to their common error in blood transfusion procedure steps

\begin{tabular}{|c|c|c|c|c|c|c|c|c|}
\hline \multirow{3}{*}{$\begin{array}{c}\text { Common error in blood transfusion } \\
\text { procedures steps }\end{array}$} & \multicolumn{6}{|c|}{$\begin{array}{l}\text { Studied nursing } \\
(\mathrm{No}=\mathbf{3 0})\end{array}$} & \multirow{3}{*}{$X^{2}$} & \multirow{3}{*}{$\mathbf{P}$} \\
\hline & \multicolumn{2}{|c|}{ Pre } & \multicolumn{2}{|c|}{$\begin{array}{l}\text { Immediately } \\
\text { Post }\end{array}$} & \multicolumn{2}{|c|}{$\begin{array}{c}\text { After one } \\
\text { month }\end{array}$} & & \\
\hline & No & $\%$ & No & $\%$ & No & $\%$ & & \\
\hline \multicolumn{9}{|l|}{ Pre transfusion } \\
\hline $\begin{array}{l}\text { Check the patient's identifications } \\
\text { Not done } \\
\text { Done }\end{array}$ & $\begin{array}{l}11 \\
19\end{array}$ & $\begin{array}{l}36.7 \\
63.3\end{array}$ & $\begin{array}{c}5 \\
22\end{array}$ & $\begin{array}{l}16.7 \\
73.3\end{array}$ & $\begin{array}{l}11 \\
19\end{array}$ & $\begin{array}{l}36.7 \\
63.3\end{array}$ & 21.36 & $0.000 *$ \\
\hline $\begin{array}{l}\text { Check the blood for any unusual. } \\
\text { Not done } \\
\text { Done }\end{array}$ & $\begin{array}{l}10 \\
20\end{array}$ & $\begin{array}{l}33.3 \\
66.7\end{array}$ & $\begin{array}{c}7 \\
23\end{array}$ & $\begin{array}{l}23.3 \\
76.7\end{array}$ & $\begin{array}{l}11 \\
19\end{array}$ & $\begin{array}{l}36.7 \\
63.3\end{array}$ & 5.22 & 0.121 \\
\hline $\begin{array}{l}\text { Check the expirations date on the } \\
\text { bag. } \\
\text { Not done } \\
\text { Done }\end{array}$ & $\begin{array}{l}20 \\
10\end{array}$ & $\begin{array}{l}66.7 \\
33.3\end{array}$ & $\begin{array}{c}2 \\
28\end{array}$ & $\begin{array}{c}6.7 \\
93.3\end{array}$ & $\begin{array}{l}10 \\
20\end{array}$ & $\begin{array}{l}33.3 \\
66.7\end{array}$ & 28.13 & $0.000 *$ \\
\hline $\begin{array}{l}\text { Instruct patient in } \mathbf{S} \& \mathbf{S} \text { of } \\
\text { transfusion reaction. } \\
\text { Not done } \\
\text { Done }\end{array}$ & $\begin{array}{l}20 \\
10\end{array}$ & $\begin{array}{l}66.7 \\
33.3\end{array}$ & $\begin{array}{c}1 \\
29\end{array}$ & $\begin{array}{c}3.3 \\
96.7\end{array}$ & $\begin{array}{c}5 \\
22\end{array}$ & $\begin{array}{l}16.7 \\
73.3\end{array}$ & 15.42 & $0.001 *$ \\
\hline $\begin{array}{l}\text { Take patient history about previous } \\
\text { blood transfusion reaction. } \\
\text { Not done } \\
\text { Done }\end{array}$ & $\begin{array}{c}21 \\
9 \\
\end{array}$ & $\begin{array}{l}70.0 \\
30.0 \\
\end{array}$ & $\begin{array}{c}2 \\
28 \\
\end{array}$ & $\begin{array}{c}6.7 \\
93.3 \\
\end{array}$ & $\begin{array}{c}5 \\
22 \\
\end{array}$ & $\begin{array}{l}16.7 \\
73.3\end{array}$ & 6.25 & $0.010 *$ \\
\hline $\begin{array}{l}\text { Double-check the labels with pt. } \\
\text { record } \\
\text { Not done } \\
\text { Done }\end{array}$ & $\begin{array}{c}21 \\
9\end{array}$ & $\begin{array}{l}70.0 \\
30.0\end{array}$ & $\begin{array}{c}2 \\
28\end{array}$ & $\begin{array}{c}6.7 \\
93.3\end{array}$ & $\begin{array}{c}6 \\
24\end{array}$ & $\begin{array}{l}20.0 \\
80.0\end{array}$ & 21.36 & $0.001 *$ \\
\hline $\begin{array}{l}\text { Hand washing. } \\
\text { Not done } \\
\text { Done }\end{array}$ & $\begin{array}{l}10 \\
20 \\
\end{array}$ & $\begin{array}{l}33.3 \\
66.7 \\
\end{array}$ & $\begin{array}{c}3 \\
27 \\
\end{array}$ & $\begin{array}{l}10.0 \\
90.0 \\
\end{array}$ & $\begin{array}{l}10 \\
20 \\
\end{array}$ & $\begin{array}{l}33.3 \\
66.7 \\
\end{array}$ & 7.25 & $0.011 *$ \\
\hline $\begin{array}{l}\text { Take patient vital signs. } \\
\text { Not done } \\
\text { Done }\end{array}$ & $\begin{array}{l}10 \\
20\end{array}$ & $\begin{array}{l}33.3 \\
66.7\end{array}$ & $\begin{array}{c}3 \\
27\end{array}$ & $\begin{array}{l}10.0 \\
90.0\end{array}$ & $\begin{array}{c}6 \\
24\end{array}$ & $\begin{array}{l}20.0 \\
80.0\end{array}$ & 7.25 & $0.011 *$ \\
\hline \multicolumn{9}{|l|}{ During trans fusion } \\
\hline $\begin{array}{l}\text { Initiateblood transfusion is d within } \\
\text { Not done } \\
\text { Done } \mathbf{~ m i n .} \\
\text { Done }\end{array}$ & $\begin{array}{l}10 \\
20 \\
\end{array}$ & $\begin{array}{l}33.3 \\
66.7 \\
\end{array}$ & $\begin{array}{c}3 \\
27 \\
\end{array}$ & $\begin{array}{l}10.0 \\
90.0 \\
\end{array}$ & $\begin{array}{l}10 \\
20 \\
\end{array}$ & $\begin{array}{l}33.3 \\
66.7 \\
\end{array}$ & 7.25 & $0.011 *$ \\
\hline $\begin{array}{l}\text { Invert the blood bag gently several } \\
\text { times to mix. } \\
\text { Not done } \\
\text { Done }\end{array}$ & $\begin{array}{l}10 \\
20\end{array}$ & $\begin{array}{l}33.3 \\
66.7 \\
\end{array}$ & $\begin{array}{c}3 \\
27 \\
\end{array}$ & $\begin{array}{l}10.0 \\
90.0\end{array}$ & $\begin{array}{c}6 \\
24 \\
\end{array}$ & $\begin{array}{l}20.0 \\
80.0 \\
\end{array}$ & 7.25 & 0.011* \\
\hline $\begin{array}{l}\text { Monitor vital signs. } \\
\text { Not done } \\
\text { Done } \\
\end{array}$ & $\begin{array}{l}11 \\
19 \\
\end{array}$ & $\begin{array}{l}36.7 \\
63.3 \\
\end{array}$ & $\begin{array}{c}5 \\
25 \\
\end{array}$ & $\begin{array}{l}16.7 \\
73.3 \\
\end{array}$ & $\begin{array}{l}11 \\
19 \\
\end{array}$ & $\begin{array}{l}36.7 \\
63.3 \\
\end{array}$ & 18.13 & $0.002 *$ \\
\hline $\begin{array}{l}\text { Monitor vital signs after } 30 \text { min } \\
\text { Not done } \\
\text { Done }\end{array}$ & $\begin{array}{l}11 \\
19 \\
\end{array}$ & $\begin{array}{l}36.7 \\
63.3 \\
\end{array}$ & $\begin{array}{c}5 \\
25\end{array}$ & $\begin{array}{l}16.7 \\
73.3 \\
\end{array}$ & $\begin{array}{l}11 \\
19\end{array}$ & $\begin{array}{l}36.7 \\
63.3 \\
\end{array}$ & 18.13 & $0.002 *$ \\
\hline $\begin{array}{l}\text { Worm the blood bag. } \\
\text { Not done } \\
\text { Done } \\
\end{array}$ & $\begin{array}{c}21 \\
9 \\
\end{array}$ & $\begin{array}{l}70.0 \\
30.0 \\
\end{array}$ & $\begin{array}{c}2 \\
28\end{array}$ & $\begin{array}{r}6.7 \\
93.3 \\
\end{array}$ & $\begin{array}{c}6 \\
24\end{array}$ & $\begin{array}{l}20.0 \\
80.0 \\
\end{array}$ & 21.36 & 0.001 * \\
\hline
\end{tabular}


Afaf Abdelaziz Basal \& MoneraBassunyElshemy

\begin{tabular}{|c|c|c|c|c|c|c|c|c|}
\hline \multirow{3}{*}{$\begin{array}{l}\text { Common error in blood } \\
\text { transfusion procedures }\end{array}$} & \multicolumn{6}{|c|}{$\begin{array}{l}\text { Studied nursing } \\
\quad\left(\mathrm{No}_{0}=\mathbf{3 0}\right)\end{array}$} & \multirow{3}{*}{$X^{2}$} & \multirow{3}{*}{$\mathbf{P}$} \\
\hline & \multicolumn{2}{|c|}{ Pre } & \multicolumn{2}{|c|}{$\begin{array}{c}\text { Immediatel } \\
\text { y Post }\end{array}$} & \multicolumn{2}{|c|}{$\begin{array}{l}\text { After one } \\
\text { month }\end{array}$} & & \\
\hline & No & $\%$ & No & $\%$ & No & $\%$ & & \\
\hline \multicolumn{9}{|l|}{ Post transfusion } \\
\hline $\begin{array}{l}\text { Obtain vital signs. } \\
\text { Not done } \\
\text { Done }\end{array}$ & $\begin{array}{l}20 \\
10\end{array}$ & $\begin{array}{l}66.7 \\
33.3 \\
\end{array}$ & $\begin{array}{c}6 \\
24 \\
\end{array}$ & $\begin{array}{l}20.0 \\
80.0\end{array}$ & $\begin{array}{l}10 \\
20\end{array}$ & $\begin{array}{l}33.3 \\
66.7 \\
\end{array}$ & 7.56 & $0.022 \%$ \\
\hline $\begin{array}{l}\text { Compare vital signs with } \\
\text { baseline measurements. } \\
\text { Not done } \\
\text { Done }\end{array}$ & $\begin{array}{l}20 \\
10\end{array}$ & $\begin{array}{l}66.7 \\
33.3\end{array}$ & $\begin{array}{c}6 \\
24\end{array}$ & $\begin{array}{l}20.0 \\
80.0\end{array}$ & $\begin{array}{l}10 \\
20\end{array}$ & $\begin{array}{l}33.3 \\
66.7\end{array}$ & 7.56 & $0.022 \%$ \\
\hline $\begin{array}{l}\text { Hand washing. } \\
\text { Not done } \\
\text { Done }\end{array}$ & $\begin{array}{l}17 \\
13 \\
\end{array}$ & $\begin{array}{l}56.7 \\
43.3 \\
\end{array}$ & $\begin{array}{c}3 \\
27\end{array}$ & $\begin{array}{l}10.0 \\
90.0\end{array}$ & $\begin{array}{l}10 \\
20 \\
\end{array}$ & $\begin{array}{l}33.3 \\
66.7 \\
\end{array}$ & 14.25 & 0.001 * \\
\hline $\begin{array}{l}\text { Worm the blood bag in } \\
\text { appropriate manner. } \\
\text { Not done } \\
\text { Done }\end{array}$ & $\begin{array}{c}21 \\
9\end{array}$ & $\begin{array}{l}70.0 \\
30.0\end{array}$ & $\begin{array}{c}2 \\
28\end{array}$ & $\begin{array}{c}6.7 \\
93.3\end{array}$ & $\begin{array}{c}6 \\
24\end{array}$ & $\begin{array}{l}20.0 \\
80.0\end{array}$ & 21.36 & 0.001 * \\
\hline $\begin{array}{l}\begin{array}{r}\text { Document the time the } \\
\text { infusion was start and } \\
\text { complete. }\end{array} \\
\text { Not done } \\
\text { Done }\end{array}$ & $\begin{array}{c}21 \\
9\end{array}$ & $\begin{array}{l}70.0 \\
30.0\end{array}$ & $\begin{array}{c}2 \\
28\end{array}$ & $\begin{array}{c}6.7 \\
93.3\end{array}$ & $\begin{array}{c}6 \\
24\end{array}$ & $\begin{array}{l}20.0 \\
80.0\end{array}$ & 21.36 & $0.001 *$ \\
\hline
\end{tabular}

*Significant $\mathbf{P}<0.05$

Table (5):- Levels of error in blood transfusion procedures among studied nurses.

\begin{tabular}{|c|c|c|c|c|c|c|}
\hline \multirow{3}{*}{ Time of assessment } & \multicolumn{6}{|c|}{$\begin{array}{l}\text { Levels of error in blood transfusion procedures } \\
\qquad\left(\mathrm{No}_{0}=30\right)\end{array}$} \\
\hline & \multicolumn{2}{|c|}{$\begin{array}{l}\text { Low } \\
(0-6)\end{array}$} & \multicolumn{2}{|c|}{$\begin{array}{l}\text { Moderate } \\
(7-12)\end{array}$} & \multicolumn{2}{|c|}{$\begin{array}{c}\text { High } \\
(13-18)\end{array}$} \\
\hline & $\mathbf{N}$ & $\%$ & $\mathbf{N}$ & $\%$ & $\mathbf{N}$ & $\%$ \\
\hline Pre-program & 1 & 3.3 & 6 & 20.0 & 23 & 76.7 \\
\hline Immediately post-program & 22 & 73.3 & 5 & 16.7 & 3 & 10.0 \\
\hline After one month & 17 & 56.7 & 8 & 26.7 & 5 & 16.7 \\
\hline $\mathbf{F}$ & \multicolumn{6}{|c|}{115.23} \\
\hline $\mathbf{P}$ & \multicolumn{6}{|c|}{ 0.001* } \\
\hline
\end{tabular}

*Significant $\mathbf{P}<\mathbf{0 . 0 5}$

\section{Discussion:}

Nursing action during blood transfusion aim at prevention or early recognition of adverse transfusion reaction. Preparation of patient for transfusion therapy is critical and institutional blood product administration procedures must be carefully followed. ${ }^{(15)}$ Every medical procedure bears potential benefits to thepatient as 
well as potential risks. These must be evaluatedwhenever transfusion of blood or blood components is considered.Mahmoud (2004) ${ }^{(\mathbf{1 6})}$ reported that teaching programs for nursing staff constitutes an important part. These programs are urgently designed to assist staff nurses in developing and enhancing their skills needed to provide high standards of care to their patients. This agreed with the present study as nurse's knowledge and practice improved after implementation of the health teaching program. The results of the present study showed that before the implementedteaching program (pre-test) poor level of knowledge about blood, blood transfusion and complications of blood transfusion, which reflects the lack in their scientific knowledge. The implementation of the teaching program showed an improvement in the nurses' level of knowledge. This may due to low training of nurses .This agreed with the study of Ruggiero et al (17) whichconducted to assess blood transfusion knowledge and practice among 100 nurses in Turkey. Nurses knowledge and practice related to blood transfusion were measured against a total score of 100 . None of the participating nurses achieved a score of 100 , and only a few had scores higher than 50. Although a positive correlation existed between the nurses knowledge and practice scores, the correlation coefficient was insignificant. The results of the study showed insufficient knowledge about blood transfusion, which was reflected in undesirable practice

Also the study of Nathan etal 2006 $^{(18)}$ concluded that low and moderate level of knowledge in approximately half of their samples and on the importance of blood transfusion procedure, suggesting that more attempts should be made to build up knowledge about blood transfusion. Moreover all staff involved in the blood transfusion process should receive training and be assessed as competent. Subsequently, staff should be competency assessed. ${ }^{(19)}$

The present study revealed poor score of knowledge about blood transfusion pre teachingprogram while there was a great improvement in knowledge score about complications of blood transfusion immediately after application of teaching program but decrease slightly after one month of follow up. This constant with Wang et. al. $2008^{(20)}$ who stated that it is difficult for staff to retain knowledge and skills that may not be used on a dailybasis and have to be reproduced without warning. All staff involved in the blood transfusion process should receive regular (minimum 2 yearly) training and be assessed as competent in accordance with the relevant regulations, standards and notices.

In the present study nearly two third of nurses not measure vital signs correctly before the implementation of the program while one third of them only after one month of implement the program they depend greatly on measuring temperature. This due to lack of the staff and increase work load in the department as they mentioned it also lack of their knowledge. The National Confidential Enquiry into Patient Outcomeand Death (NCEPOD2005) ${ }^{(\mathbf{2 1})}$ reported that in critically ill medical patients, the respiratory rate is an earlyand important indicator of deterioration. Dyspnea and tachypnea may both befeatures of serious transfusion reactions, and while routine monitoring ofrespiratory rate is unnecessary during a transfusion, a baseline measurementbefore the transfusion starts is recommended.

According to SHOT 2006 ${ }^{(22)}, 34 \%$ of reactions occur more than 30 minutes afterthe transfusion starts. Therefore there should be regularly visual monitoring of thePatient throughout the transfusion 
episode with additional observations asneeded.

The current study revealed that a great improvement in the practice score levels obtained by nurses after implementation of nursing intervention program Immediately and after one month of follow up. This has been concluded by the presence of significant differences between results of pre-test and post-test. This may be attributed to lack of continuous education and in-service training program.

In the present study high percent of nurses done low level of error Immediately post-program and After one month. This due to the continued nursing education programs will increase knowledge, practice and also improve attitudes. This agree with Deyetal 2006 ${ }^{(\mathbf{2 3})}$ who stated that Transfusion of blood saves life. An error in blood transfusion, at the same time, threating life. Nurses being responsible for the final bedside check before transfusion, have the final opportunity to prevent a mis-transfusion. An understanding and knowledge of the pathophysiology of transfusion reactions, symptoms and treatment is essential to safely administer and monitor transfusion.

\section{Conclusion:}

Based on the results of the present study, it can be concluded that:

Nurse's knowledge and practice regarding blood transfusion and its complications in the general medical departments and hematological unit at Tanta University Hospital were poor before implementing structured teaching program but therewere great improvement in the knowledge and practice score levels obtained by nurses after implementation of structured teaching program immediately and after one month of follow up.

\section{Recommendation:}

- Continued nursing education and inservice training programs in general medical departments and hematological unit should be well organized within Tanta University Hospital

- Encouraged newly and old employed nurse to attend scientific meetings and conferences to keep pace with the rapidly growing of knowledge and practice necessary for proper nursing service.

- Adequate supplies and facilities should be available in the unit to help and facilitate the nurse work.

- Periodic monitoring of nurses knowledge and practice to evaluate the level of nurses.

- Further studies should be replicated on longitudinal bases for follow up.

\section{References:}

1- Bielefeldt S, and DeWitt J, (2009). The rules of transfusion: Best practices for blood product administration, American nurse today, February 2009.4(2):27-30

2- Thompson, C.L, Edwards, C., Stout, L (2008). Blood transfusions 1: how to monitor for adverse reactions. Nursing Times; 104: 2, 32-33.

3- Gray, A., Hearnshaw, K., Izatt, C., Kirwan, M., (2007). Safe transfusion of blood and blood components. Nursing Standard 2007, 21 (51), 4047.

4- AnneWaugh, Allison Grant.( 2006), Anatomy and physiology in health and illness 2006 , 9th edition published by Wolters,p1001-1009.

5- Carven R., (2007): Fundamentals of Nursing Human Health and Function, Intravenous therapy, ch. $30,5^{\text {th }}$ ed., lippicottcompany: 637.

6- Rosdahi C and Kowalski M, (2012), Textbook of Basic Nursing, ten edition Lippincott Williams company, chapter 23, 250-56.

7- Vamvakas EC, Blajchman MA. (2009); Transfusion-related mortality: the ongoing risks of allogeneic blood transfusion and the available strategies 
for their prevention. Blood. 113(15):3406-17.

8-Brunner L.S., Smeltzer S.C., Bare B. G., Hinkle J.L. and Cheever K.H., (2009): Lippincott Williams \& Wilkins Brunner \&Suddarth's Textbook of Medical Surgical Nursing,:1038:40.

9-Gajic O. and Moore S. B., (2005). Transfusion -related acute lung injury, Mayo clinical process, : 766:80.

10-WU Y.Y. and Snyder E.L., (2005).Hematology: basic principles and practice, Transfusion reaction $4^{\text {th }}$ ed., pheladelphia.:103-4

11- Eleftherios C. Vamvakas and Morris A. Blajchman(2009). Transfusionrelated mortality: the ongoing risks of allogeneic blood transfusion and the available strategies for their preventionApril 9, 2009; Blood: 113 (15)

12- Hendrickson JE, Hillyer CD.(

2009). Noninfectious serious hazards of transfusion. AnesthAnalg.;108(3):75969.

13- Carven R., (2007). Fundamentals of nursing human health and function, Intravenous therapy, ch. $30,5^{\text {th }}$ ed., lippicott company, :. 637 .

14- Khalil , ,. Mohammad Z, Ez El-Deen M, and Ahmed N, (2013). Impact of Implementing a Designed Nursing Intervention Protocol on nuses' knowledge and practice Regarding patients under going Blood Transfusion. Master thesis, Faculty of Nursing, Assiut University

15-Ignatavicius D, WinkelmanCh, (2013). Medical surgical nursing patient centered collaboration care, seven edition, Elsevier Saunders, chapter 17.
16-Mahmoud. A., (2004): Nursing role toward patients undergoing abdominal laparoscopic surgery; a suggested training program. MD thesis in MSN Assiut University.

17- Ruggiero A, Riccardi R.(2002

).Interventions for anemia in pediatric cancer patients". Med PediatrOncol. Oct;39(4):400 -51

18-Nathan M, Selwood K. (2006). The use of blood products in pediatric oncology units in the UK'. Pediatric Nurs. Sep;18(7): 7-14.

19- British Committee for Standards in Haematology(2009). Guideline on the Administration of Blood Components

20-Wang. E.E., Quinones. J., Fitch, M.T., Dooley-Harsh, S., GriswoldTheodorson, S., Medzon, R., Korley, F., Laack, T., Robinett, A., Clay, l. (2008) Developing technical expertise in emergency medicine - the role of simulation in procedural skill acquisition. Academic Emergency Medicine, 15 (1) 1-12

21- National Confidential Enquiry into Patient Outcome and Death (NCEPOD) (2005)An Acute Problem. NCEPOD. London www.ncepod.org.uk

22-Serious Hazards of Transfusion (SHOT) scheme (1996 - 2008) SHOT Annual reports1996 - 2008. SHOT office.Manchester. www.shotuk.org/home.htm

23-Dey A, SinghnS,(2006).Transfusion transmitted leishmaniasis a case report and review of literature" Indian Journal med Microbial . july.24(3):165-70. 